\title{
LABORATORY WORK ON TOTAL SUCTION CALIBRATION CURVE FOR WHATMAN \#42 FILTER PAPER
}

\author{
Yusep Muslih Purwana \\ Geoscience Research Group, Prodi Teknik Sipil, Universitas Sebelas Maret, Jl. Ir. Sutami 36 A Surakarta \\ Email:ymuslih@yahoo.com,ymuslih@ft.uns.ac.id
}

\begin{abstract}
Soil suction is one of main parameter in unsaturated soil mechanics as its measurement is as very important as pore water pressure measurement for effective stress concept in saturated soil mechanics. Basically, the measurement of soil suction can be classified into 2 categories; direct and indirect method. In the first method, negative pore water pressure is measured directly to obtain matric suction, whereas in indirect method, suction is obtained indirectly by using salt solution and censor. Calibration is then required to establish the relationship between concentration of salt solution and censor. Filter paper method is considered as the simplest method and relatively low cost compare to other method. The studies conducted by many investigators indicate that calibration curve from one type to another type of filter paper is quite different. This paper presents the basic concepts of laboratory work on establishing total suction calibration curve for Wahtmann \#42 filter paper. The work has been conducted using $\mathrm{NaCl}$ and $\mathrm{KCl}$ solutions with different molality to generate different suction. The result indicates that the higher molality of solution, the higher suction is generated. The calibration curve from $\mathrm{KCl}$ exhibits a bit higher compare to the one from $\mathrm{NaCl}$. The difference of both curves most probably is due to the difference of equilibration period and suction source.
\end{abstract}

Keywords: Calibration curve, filter paper, suction, unsaturated soil

\section{GENERAL}

Soil suction is one of main parameter in unsaturated soil mechanics. Its measurement is as very important as pore water pressure measurement for effective stress concept in saturated soil mechanics (Houston et al. 1994).

Basically, the measurement of soil suction can be classified into 2 categories: direct and indirect method. In the first method, negative pore water pressure is measured directly to obtain matric suction. Tensiometer and null type pressure plate are examples of this method. In indirect method, suction is obtained indirectly by using salt solution and censor. Calibration is required to establish the relationship between concentration of salt solution and censor. This calibration test usually performed in equilibrium at particular temperature. Psychrometer, electric/thermal conductivity censor and filter paper methods are three examples of indirect method.

Recently, filter paper method is considered as the simplest method and relatively low cost compare to other method. This method is able to measure high range of suction $(0-30000 \mathrm{KPa})$. The studies conducted by many investigators indicate that calibration curve from one type to another type of filter paper is quite different. Although filter paper is an industrial material which is produced under high technology control, calibration should be made for every batch of filter paper (Marinho and Oliveira, 2005).

This paper presents theoretical concept and laboratory practice for filter paper calibration curve for total suction. The result of this study will briefly be compared and discussed to other available curves.

\section{MATRIC, OSMOTIC, AND TOTAL SUCTION}

There are some definitions of soil suction. Suction may be defined as unit attractive force of the soil for water. It also has been defined as force needed to take away a soil water molecule from the soil into vapour phase (Bulut, 1996). 
Commonly, soil suction is defined as free energy state of soil water. The free energy of the soil water can be measured in terms of the partial vapour pressure of the soil water (Fredlund and Rahardjo, 1993).

There are 3 kinds of soil suction: total suction, matric suction and osmotic suction. Matric suction is suction coming from capillary force, soil texture, and adsorption forces of soil particles. Houston (1994) has defined that matric suction is the affinity of soil has for water in the absence of any salt content gradient in the water. Osmotic suction is suction coming from salt concentration differences between one point and another point in the soil mass. Total suction is suction coming from matric suction and osmotic suction. Total suction, matric suction and osmotic suction can be written in mathematics expression as:

Where

$$
\Psi=\left(u_{a}-u_{w}\right)+\pi
$$

$$
\begin{aligned}
\psi & =\text { total suction } \\
\left(u_{a}-u_{w}\right) & =\text { matric suction } \\
\pi & =\text { osmotic suction }
\end{aligned}
$$

Thermodynamics theory may be applied as basic concept for total suction measurement. In thermodynamics term, total suction can be considered as free energy state of soil pore water, which may be measured in term of partial pressure vapour of soil pore water at equilibrium (Houston et al. 1994; Leong et al., 2002; Likos and Lu 2002, Bulut and Wray 2005, Marinho and Oliveira 2005). Total suction (in KPa) above free surface/flat of pure water can be determined by using Kevin's Equation as:

$$
\psi=\frac{R T}{V} \ln \left(\frac{P}{p_{0}}\right)
$$

Where

$$
\begin{aligned}
& \mathrm{R}=\text { universal gas constant }\left(8.31432 \mathrm{~J} \mathrm{~mol}^{-1} \mathrm{~K}^{-1}\right) \\
& \mathrm{T}=\text { Absolute temperature }\left(273.16+\mathrm{t}^{\circ} \mathrm{C}\right) \\
& \mathrm{V}=\text { molecular volume of water, volume of } 1000 \text { moles of liquid water }\left(0.018 \mathrm{~m}^{3}\right) \\
& \mathrm{P}=\text { partial pressure of pore water vapour }(\mathrm{kPa}) \\
& \mathrm{P}_{0}=\text { saturation pressure of water vapour over a flat surface of pure water at the same temperature }(\mathrm{kPa})
\end{aligned}
$$

If $\mathrm{P} / \mathrm{P}_{0}$ is called relative humidity, than the equation (2) can be written as:

$$
\psi=\frac{R T}{V} \ln (R H)
$$

At constant temperature of $20^{\circ} \mathrm{C}$, the equation becomes (Fredlund and Rahardjo, 1993):

$$
\psi=-135022 \ln (R H)
$$

Equation (4) indicates that total suction can be determined by measuring relative humidity in the surrounding closed system. RH $100 \%$ indicates that no suction, while RH < 100\% indicates the presence of suction in the system. Relative humidity measurement can be conducted by direct method such as psychometer or by indirect method using filter paper method. The description of filter paper method will be presented in this paper, whereas psychometer method is beyond of this study.

The principle of filter paper method in soil suction measurement is based on assumption that filter paper comes into equilibrium with soil having specific suction (Fredlund and Rahardjo, 1993). The equilibrium can be reached by transferring moisture from soil to filter paper, either through liquid flow or water vapour flow. Water, in term of liquid 
or vapour may move from wet soil to dry filter paper. This movement occurs continuously until equilibrium is reached. In equilibrium, the suction of soil and filter paper will be the same. Total suction can be determined by measuring absorbed moisture by filter paper through vapour flow, whereas matric suction can be determined by measuring absorbed water through liquid flow. In short, the soil suction can be determined by measuring moisture content of filter paper.

Filter paper calibration curve should be established prior to measure soil suction. Calibration curve is a curve that relates moisture content of filter paper and suction value of the system at equilibrium. In the past, a calibration curve for particular filter paper can be use either for total or matric suction. However, recent studies indicate that for total and matric suction measurement, two separate calibration curves should be made, one for total suction and one for matric suction (Houston et al., 1994; Ridley, 1995; Bulut and Wray, 2005). In other word, total suction calibration curve will only be applicable for total suction. Likewise, matric suction calibration curve will only be applicable for measuring soil matric suction.

Referring to equation (4), calibration curve for filter paper can be made by plotting moisture content of filter papers vs. suction. Some salt solutions such as $\mathrm{NaCl}, \mathrm{KCl}, \mathrm{MgNO}_{3}, \mathrm{NH}_{4} \mathrm{Cl}$, and $\mathrm{CaSO}_{4}$ with different molality are commonly used to generate relative humidity of water vapour above solution. ASTM D 5298-94 provides relative humidity values generated from $\mathrm{NaCl}$ and $\mathrm{KCl}$ solutions at $20^{\circ} \mathrm{C}$ (Table 1). Molality of solution is calculated using equation (5) and (6). Figure 1 shows the linear curves of molality vs. suction which the values of $R^{2}$ are very close to 1 .

Table 1. Relative humidity and suction values generated from $\mathrm{NaCl}$ and $\mathrm{KCl}$ at $20^{\circ} \mathrm{C}$ (except column 2 and 4 , all data are taken from ASTM D 5298-94)

\begin{tabular}{|c|c|c|c|c|c|c|}
\hline \multicolumn{2}{|l|}{$\mathrm{NaCl}$} & \multicolumn{2}{|l|}{$\mathrm{KCl}$} & \multirow[b]{2}{*}{ RH } & \multicolumn{2}{|c|}{ Suction } \\
\hline $\mathrm{g} / 1000 \mathrm{mg}$ water & Molality & $\mathrm{g} / 1000 \mathrm{mg}$ water & Molality & & $\mathrm{KPa}$ & $\begin{array}{c}\mathrm{Log} \\
(\mathrm{KPa})\end{array}$ \\
\hline 1.3 & 0.022 & 1.7 & 0.023 & 0.99927 & -98 & 1.99 \\
\hline 3.8 & 0.065 & 5.3 & 0.071 & 0.99774 & -310 & 2.49 \\
\hline 13.1 & 0.224 & 17 & 0.228 & 0.99278 & -980 & 2.99 \\
\hline 39 & 0.667 & 52.7 & 0.707 & 0.97764 & -3099 & 3.49 \\
\hline 122.5 & 2.096 & 165.0 & 2.213 & 0.93008 & -9800 & 3.99 \\
\hline
\end{tabular}

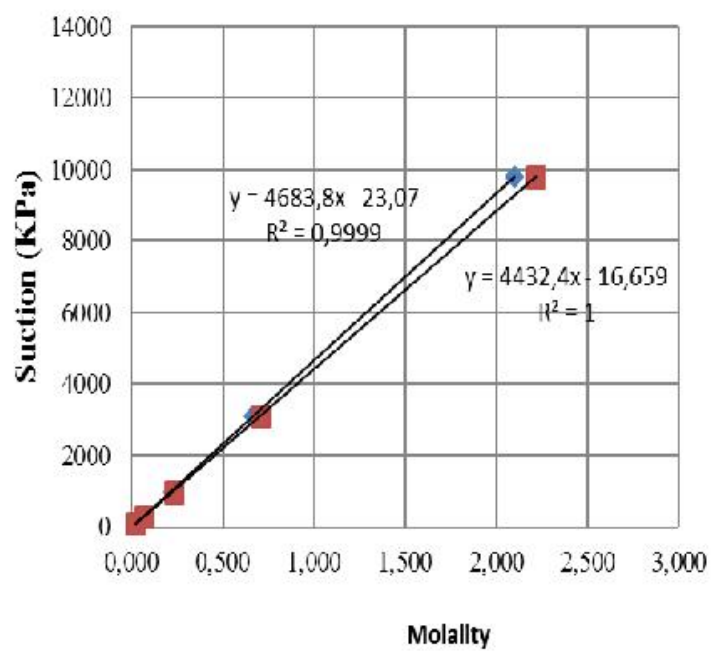

* $\mathrm{NaCl}$ solution $\quad \mathrm{KCl}$ solulion

Figure 1. Suction values generated from different molality of $\mathrm{NaCl}$ and $\mathrm{KCl}$ solutions at $20^{\circ} \mathrm{C}$

(Data are taken from ASTM D 5298-94) 


\section{EXPERIMENTAL PROCEDURE}

For generating suction, $\mathrm{NaCl}$ and $\mathrm{KCl}$ solution with different molality starting from $0.1 \mathrm{~m}, 0.5 \mathrm{~m}, 1 \mathrm{~m}, 2 \mathrm{~m}, 4 \mathrm{~m}$, and maximum $6 \mathrm{~m}$ has been made. The molality of solution is calculated as:

$$
\text { molality }=\frac{\text { mole of soiute }}{\text { mass of solvent }(\mathrm{kg})}
$$

where

$$
\text { mole of solute }=\frac{\text { mass of solute }}{\text { molecular mass of solute }}
$$

$\mathrm{NaCl}$ and $\mathrm{KCl}$ are purchased from Rowe Scientific which is having molecular mass of 58.44 and 74.55 respectively (Figure 2a). To make 1 molal $\mathrm{NaCl}$ solution, 1 mole $\mathrm{NaCl}$ is mixed with $1000 \mathrm{ml}$ distilled water. 1 mole $\mathrm{NaCl}$ can be obtained by weighing 58.44 gr of pure $\mathrm{NaCl}$. Likewise, $74.55 \mathrm{gr} \mathrm{KCl}$ is mixed with $1000 \mathrm{ml}$ distilled water to make 1 molal $\mathrm{KCl}$. Table 2 illustrates approximation of solute mass of $\mathrm{NaCl}$ and $\mathrm{KCl}$ for providing desired solutions. $50 \mathrm{ml}$ of each solution is then poured into $130 \mathrm{ml}$ glass jar (Figure 2b).

Table 2. Solute mass for different molality of $\mathrm{NaCl}$ and $\mathrm{KCl}$

\begin{tabular}{|r|r|r|r|}
\hline \multicolumn{4}{|c|}{ Distilled water (solvent): $1000 \mathrm{ml}$} \\
\hline \multicolumn{2}{|c|}{ Solute mass (gr) } & \multicolumn{2}{|c|}{ Molality } \\
\hline $\mathrm{NaCl}$ & $\mathrm{KCl}$ & $\mathrm{NaCl}$ & $\mathrm{KCl}$ \\
\hline 6 & 7.5 & 0.103 & 0.101 \\
\hline 29 & 37 & 0.496 & 0.496 \\
\hline 59 & 75 & 1.010 & 1.006 \\
\hline 117 & 149 & 2.002 & 1.999 \\
\hline 234 & 298 & 4.004 & 3.997 \\
\hline 350 & 447 & 5.989 & 5.996 \\
\hline
\end{tabular}

In this study, $55 \mathrm{~mm}$ Whatman \# 42 ashless filter paper of batch K11776722 is used. Prior to place in glass jars, filter papers are oven dried at $105^{\circ} \mathrm{C}$ for at least 24 hours, and placed in desiccators. Filter paper is then suspended $+10 \mathrm{~mm}$ above solution surface in glass jar and is held by steel wire (Figure 2c). Immediately after placing filter paper, glass jar is covered tightly by plastic lid, sealed with electric tape (Figure $2 \mathrm{~d}$ ), and put into insulated plastic box. The position of glass jars is tilted $10^{\circ}-20^{\circ}$ to avoid droplet due to condensation. The ambient temperature is controlled at near $20^{\circ} \mathrm{C}$, while the temperature of insulated plastic box is checked regularly by using thermocouple thermometer. The set up of experiment is illustrated in illustrated in Figure 2.

There are different equilibration periods for filter paper test. ASTM recommended using minimum 7 days for equilibration. Marinho and Oliveira (2005) suggested 7 days for 1000 - $30000 \mathrm{KPa}$, 15 days for $250-1000 \mathrm{KPa}, 30$ days for $100-250 \mathrm{KPa}$, and more than 30 days for $0-100 \mathrm{KPa}$. However, most of studies use $7-14$ days for equilibration period. In this study, 10 and 14 days equilibration periods are taken for $\mathrm{NaCl}$ and $\mathrm{KCl}$ solutions respectively.

After 10 days, insulated plastic box is opened and all of glass jars containing $\mathrm{NaCl}$ solutions are removed. Filter paper are immediately removed from glass jar, and moisture content filter paper test are conducted then by using digital balance with accuracy of $0.0001 \mathrm{~g}$. Care has been taken when removing filter paper from glass jar into moisture tin to reduce moisture loss. It is performed as quickly as possible (within a few seconds) using tweezers and rubber gloves, without touching the filter paper. With the same procedure, filter paper test for $\mathrm{KCl}$ solution is conducted after 14 days. 


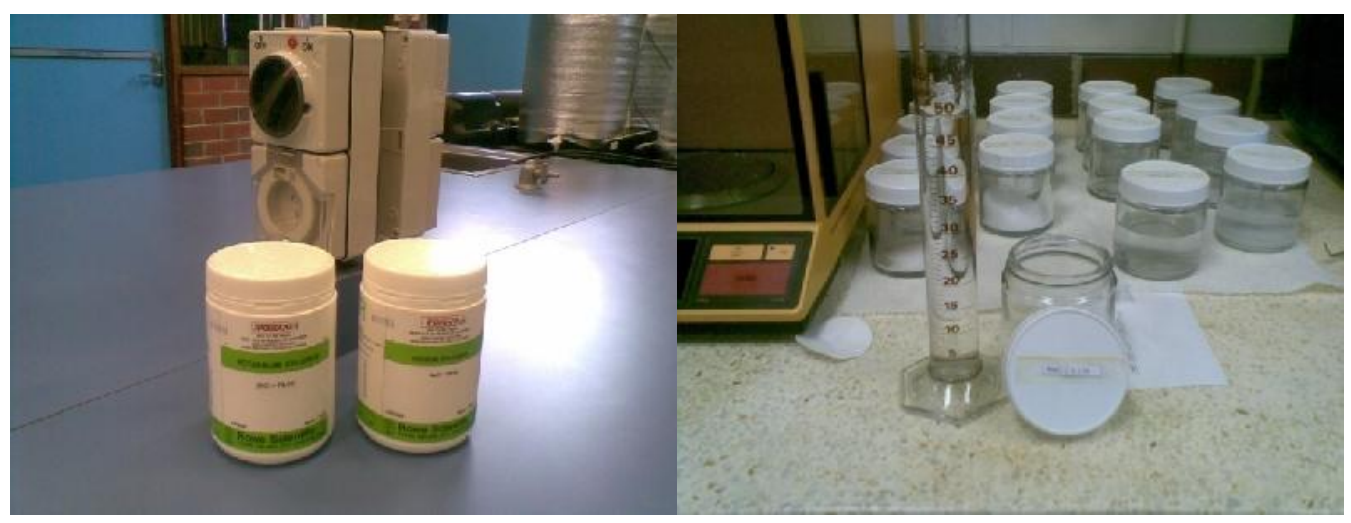

(a)

(b)

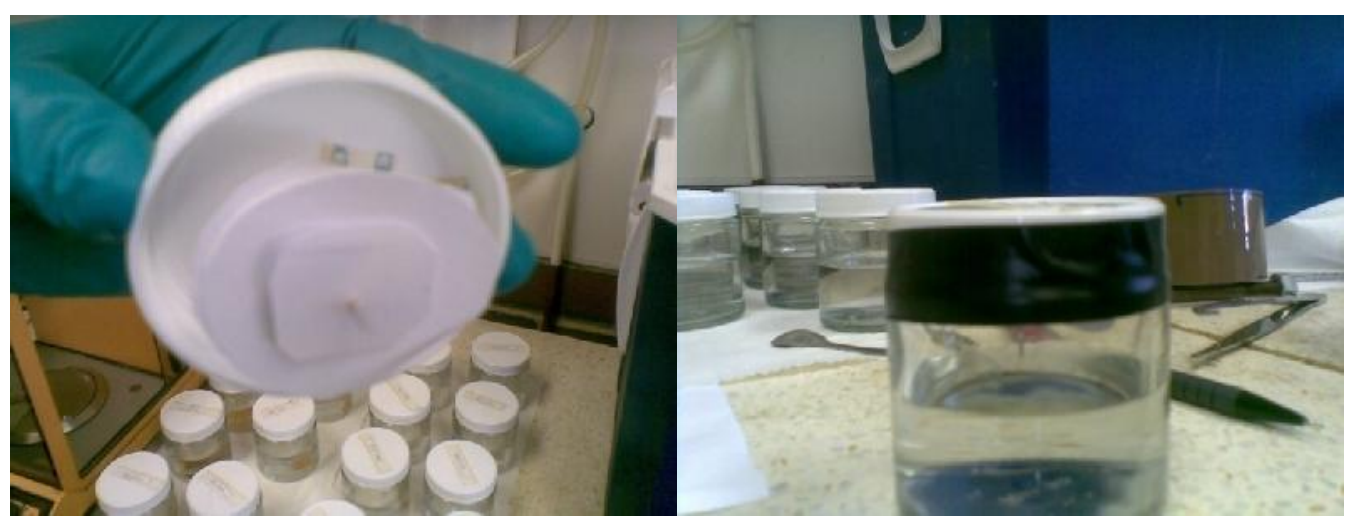

(c)

(d)

Figure 2. Photos of experimental procedure

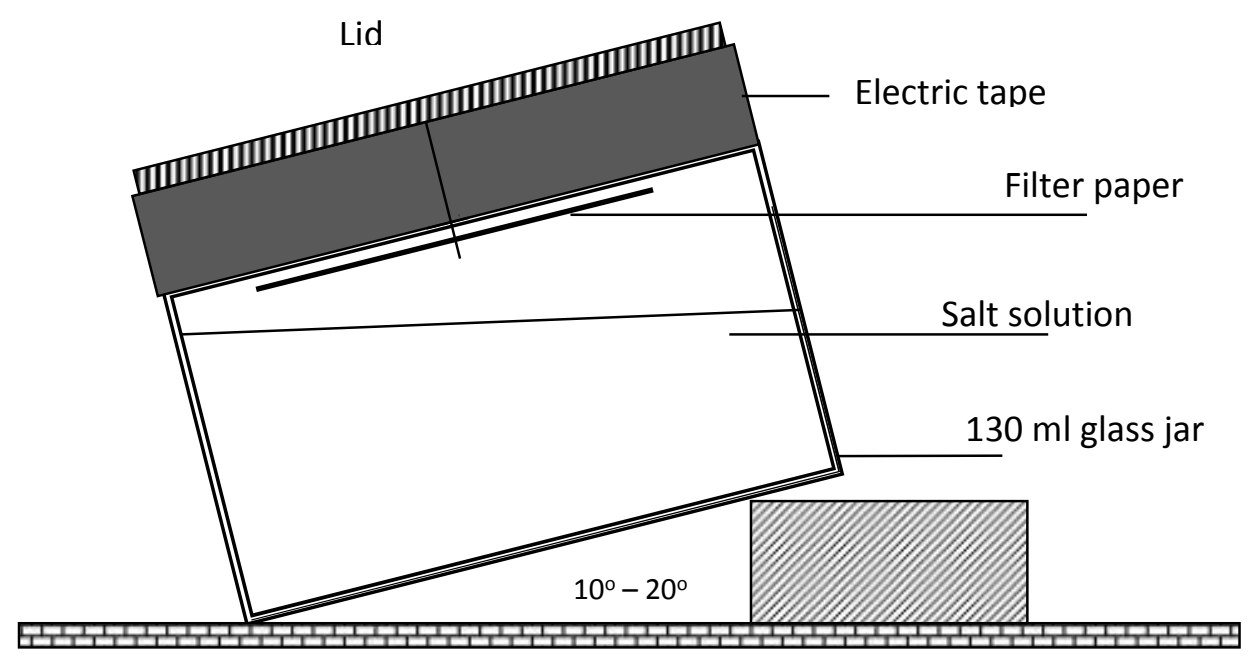

Figure 3. Experimental set up of glass jar inside insulated box 


\section{RESULT}

Table 3 and 4 show the calculation and result of moisture content filter paper test for total suction using $\mathrm{NaCl}$ and $\mathrm{KCl}$ solutions respectively. The suction value of each molality is taken from the curve of Figure 1. It can be observed that the higher molality of solution, the higher suction is generated. Suction can be calculated in cm water, bars, atm, pF or KPa, however, geotechnical engineers prefer to use KPa instead of other units. Figure 4 shows calibration curves where suction in $\log \mathrm{KPa}$

Table 3. Moisture content filter paper test using $\mathrm{NaCl}$ solution (after 10 days)

\begin{tabular}{|l|c|c|c|c|c|c|c|}
\hline Molality & $\mathrm{m}$ & 0.1 & 0.5 & 1 & 2 & 4 & 6 \\
\hline Moisture tin no & & 11 & 15 & 16 & 20 & 24 & 29 \\
\hline Cold tare mass, g & $\mathrm{Tc}$ & 38.9299 & 38.3518 & 38.3999 & 39.6136 & 40.7272 & 36.5816 \\
\hline $\begin{array}{l}\text { Mass of wet FP + cold tare } \\
\text { mass, g }\end{array}$ & $\mathrm{M} 1$ & 39.085 & 38.5004 & 38.5428 & 39.7538 & 40.8646 & 36.7166 \\
\hline $\begin{array}{l}\text { Mass of dry FP + hot tare } \\
\text { mass,g }\end{array}$ & $\mathrm{M} 2$ & 39.0472 & 38.4764 & 38.5188 & 39.736 & 40.8498 & 36.7065 \\
\hline Hot tare mass, g & $\mathrm{Th}$ & 38.9238 & 38.349 & 38.3947 & 39.6102 & 40.7224 & 36.5798 \\
\hline Mass of dry FP, g (M2-Th) & $\mathrm{Mf}$ & 0.1234 & 0.1274 & 0.1241 & 0.1258 & 0.1274 & 0.1267 \\
\hline $\begin{array}{l}\text { Mass of water in FP, g } \\
\text { (M1-M2-Tc+Th) }\end{array}$ & $\mathrm{Mw}$ & 0.0317 & 0.0212 & 0.0188 & 0.0144 & 0.01 & 0.0083 \\
\hline $\begin{array}{l}\text { Moisture content of FP } \\
\text { (Mw/Mf) }\end{array}$ & $\mathrm{W}$ & 0.2569 & 0.1664 & 0.1515 & 0.1145 & 0.0785 & 0.0655 \\
\hline Suction, kPa & $\psi$ & 454 & 2241 & 4550 & 9570 & 18939.21 & 28472.41 \\
\hline Log kPa & $\psi$ & 2.66 & 3.35 & 3.66 & 3.98 & 4.28 & 4.45 \\
\hline Suction, pF & $\psi$ & 3.66 & 4.35 & 4.66 & 4.98 & 5.28 & 5.45 \\
\hline
\end{tabular}

Table 4. Moisture content filter paper test using $\mathrm{KCl}$ solution (after 14 days)

\begin{tabular}{|l|c|c|c|c|c|c|c|}
\hline Molality & $\mathrm{m}$ & 0.1 & 0.5 & 1 & 2 & 4 & 6 \\
\hline Moisture tin no & & 11 & 12 & 16 & 23 & 26 & 29 \\
\hline Filter paper (FP) & & 2 & 1 & 1 & 2 & 2 & 2 \\
\hline Cold tare mass, g & Tc & 36.2799 & 39.7407 & 38.3976 & 37.6051 & 32.2350 & 36.5809 \\
\hline $\begin{array}{l}\text { Mass of wet FP + cold tare } \\
\text { mass, g }\end{array}$ & $\mathrm{M} 1$ & 36.4349 & 39.8940 & 38.5426 & 37.7468 & 32.3680 & 36.7142 \\
\hline $\begin{array}{l}\text { Mass of dry FP + hot tare } \\
\text { mass,g }\end{array}$ & $\mathrm{M} 2$ & 36.3968 & 39.8539 & 38.5190 & 37.7242 & 32.3546 & 36.7024 \\
\hline Hot tare mass, g & $\mathrm{Th}$ & 36.2737 & 39.7274 & 38.3941 & 37.6003 & 32.2335 & 36.5796 \\
\hline Mass of dry FP, g (M2-Th) & $\mathrm{Mf}$ & 0.1231 & 0.1265 & 0.1249 & 0.1239 & 0.1211 & 0.1228 \\
\hline $\begin{array}{l}\text { Mass of water in FP, g (M1- } \\
\text { M2-Tc+Th) }\end{array}$ & $\mathrm{Mw}$ & 0.0319 & 0.0268 & 0.0201 & 0.0178 & 0.0119 & 0.0105 \\
\hline $\begin{array}{l}\text { Moisture content of FP } \\
\text { (Mw/Mf) }\end{array}$ & $\mathrm{W}$ & 0.2591 & 0.2119 & 0.1609 & 0.1437 & 0.0983 & 0.0855 \\
\hline Suction, kPa & $\psi$ & 426.581 & 2199.541 & 4415.741 & 8848.141 & 17712.94 & 26577.74 \\
\hline Suction, log KPa & $\psi$ & 2.63 & 3.34 & 3.65 & 3.95 & 4.25 & 4.42 \\
\hline Suction, pF & $\psi$ & 3.63 & 4.34 & 4.65 & 4.95 & 5.25 & 5.42 \\
\hline
\end{tabular}




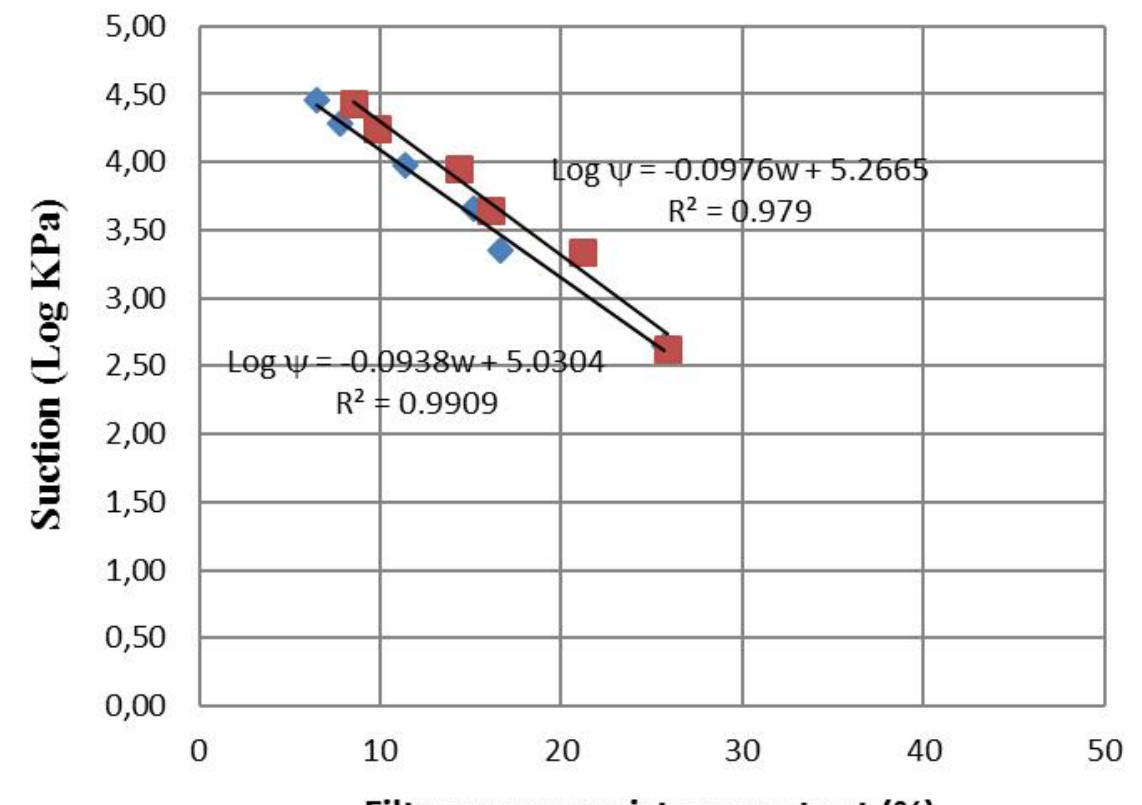

Filter paper moisture content (\%)

$\diamond \mathrm{NaCl}$ slution $\quad \mathrm{KCl}$ solution

(b)

Fig 4. Calibration Curve for Whatman \#42 Filter paper using $\mathrm{NaCl}$ and $\mathrm{KCl}$ solution separately.

\section{DISCUSION}

At equal concentration and equilibrium condition, $\mathrm{NaCl}$ generate higher suction than $\mathrm{KCl}$. The different chemical properties of both salts are probably affecting the suction. It can be shown in Figure 4 that calibration curves for total suction from $\mathrm{NaCl}$ and $\mathrm{KCl}$ are a bit different. The calibration curve from $\mathrm{KCl}$ exhibits a bit higher compare to the one from $\mathrm{NaCl}$. The curves can be expressed in equations:

$$
\log \psi=-0.0938 w+5.0304 \quad \mathrm{KPa} \text {, for } \mathrm{NaCl}
$$

And

$$
\log \psi=-0.0976 w+5.2665 \quad \mathrm{KPa}, \text { for } \mathrm{KCl}
$$

Where

$$
\mathrm{w}=\text { filter paper moisture content }
$$

The difference of both curves most probably is due to the difference of equilibration period and suction source as mentioned by Leong et al. (2002). Time period of 14 days is probably better for equilibration time than 10 days. This difference is quite small $( \pm 4 \%)$, then it may be neglected. However, both curves have similarity in gradient. If the curves are combined, we obtain another calibration curve as shown in Figure 5. The curve can be expressed as:

$\log \psi=-0.0933 w+5.1097$

$\mathrm{KPa}$

(9) 


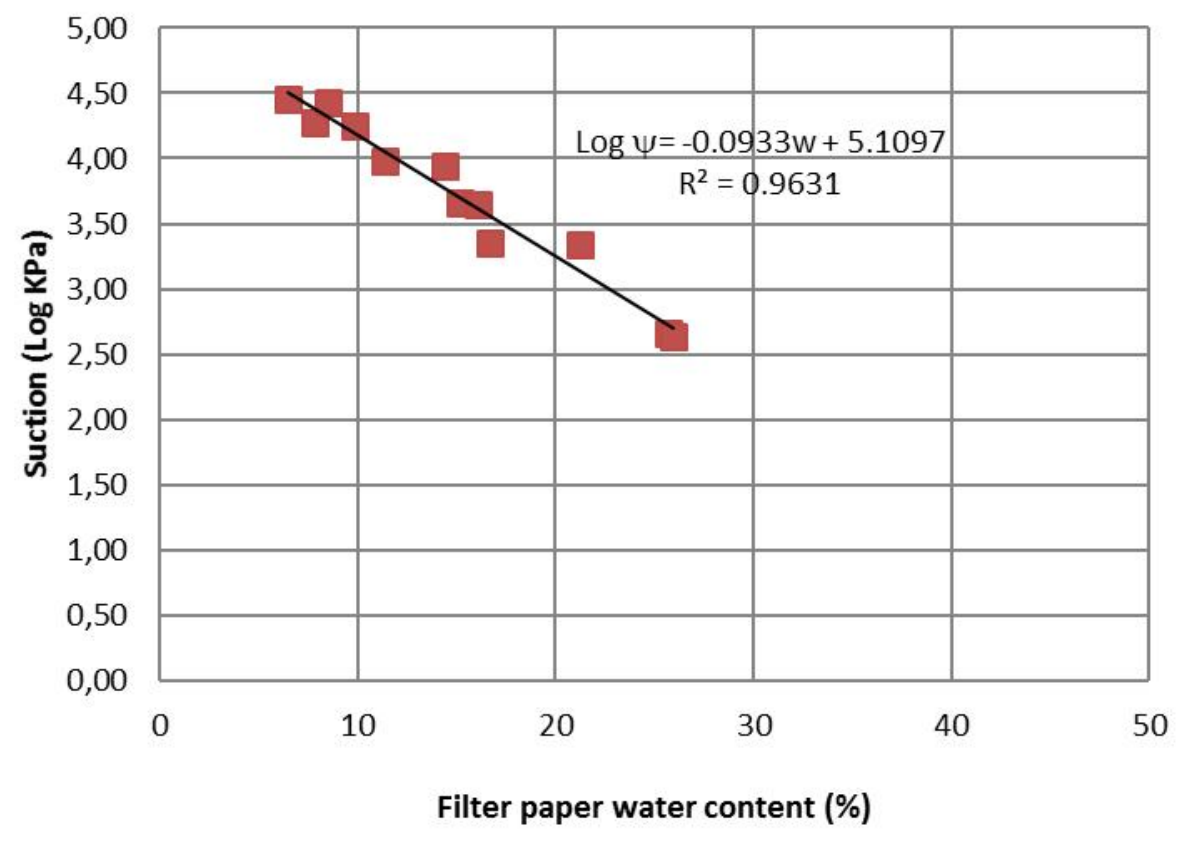

Figure 5. Calibration Curve for Whatman \#42 using combination data from $\mathrm{NaCl}$ and $\mathrm{KCl}$ solutions

Calibration curve and equation (9) is very close to the curve by Leong et.al (2002) for Whatman \#42 for total suction less than $26 \%$ (equation 14). They suggested the equations for total and matric suction as:

Matric suction:

$$
\begin{aligned}
& \log \psi=-0.0229 w+2.909 w \geq 47 \% \\
& \log \psi=-0.0673 w+4.945 w<47 \%
\end{aligned}
$$

Total suction:

$$
\begin{array}{ll}
\log \psi=-0.222 w+8.778 & w \geq 26 \% \\
\log \psi=-0.0879 w+5.31 & w<26 \%
\end{array}
$$

Equation (9) up to equation (14) can be plotted in one are plotted in one graphic as shown in Figure 6.

In this study, the maximum water absorbed by filter paper in term of moisture content is $26 \%( \pm 1000 \mathrm{KPa})$. Beyond this point, filter paper is not able to absorb the water anymore. The previous study conducted by several investigators also indicated that it is hard to obtain suction lower than $1000 \mathrm{KPa}$ by using this method. To overcome this shortcoming, they use other apparatus such as suction plate, pressure plate, vacuum desiccators, and pressure membrane. The complete matric and total suction calibration curves may be obtained by using combination of those methods. 


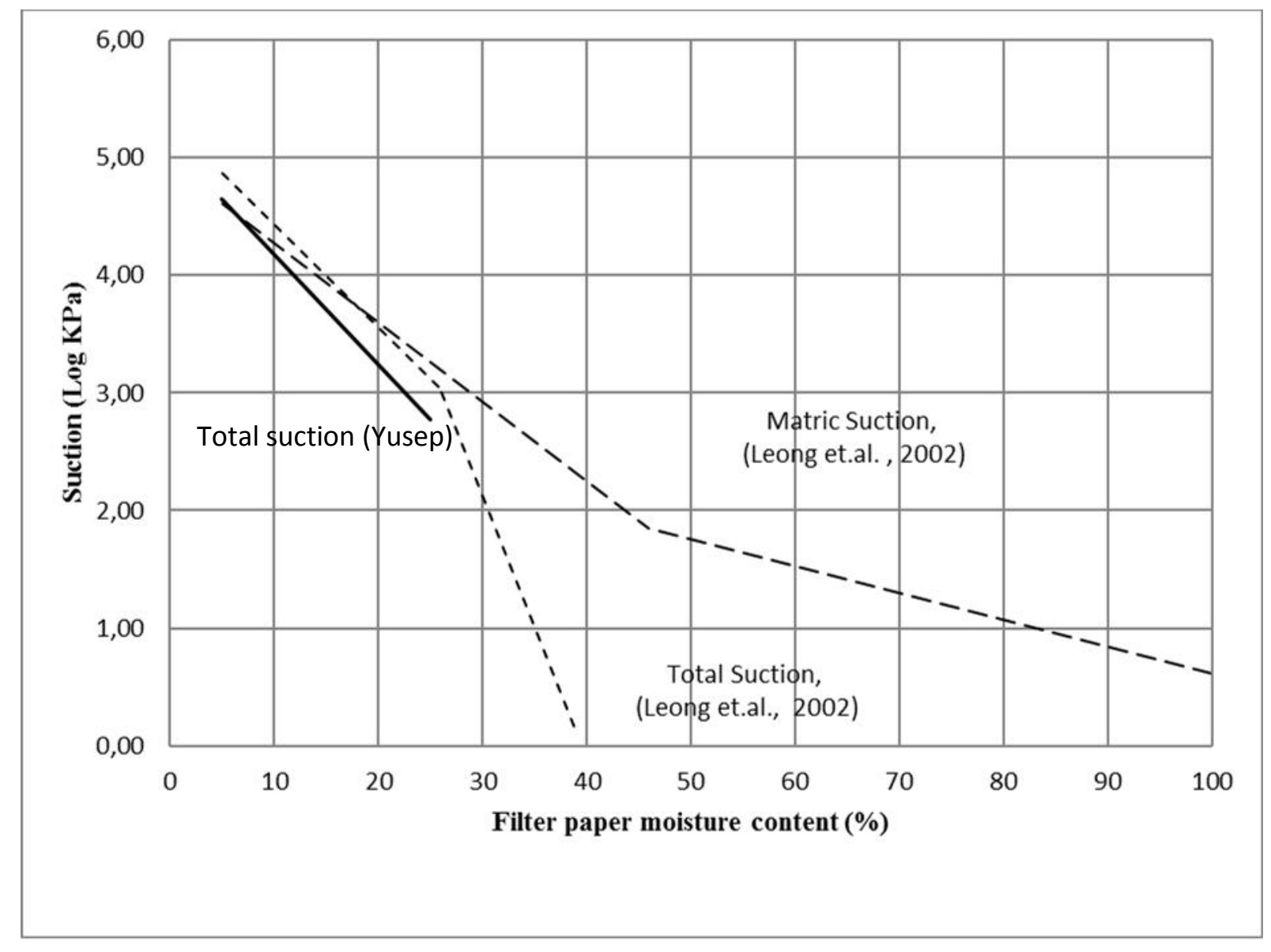

Figure 6. Calibration curve for Whatman \#42. The dashed curves (----) are resulted from Leong and Rahardo (2002)

\section{REFERENCES}

ASTM Standard D5298-94. (1994). Test Method for Measurement of Soil Potential (Suction) Using Filter Paper, 1994 Annual Book of ASTM Standards, ASTM International, West Conshohocken, PA.

Bulut R., (1996). A Re-evaluation of Filter Paper Method of Measuring Soil Suction, Master Thesis, Texas Tech University

Bulut R., and Wray W.K. (2005). ”Free Energy of Water-Suction-in Filter Papers," Geotechnical Testing Journal, Vol. 28. No. 4, pp. $1-10$.

Fredlund, D. G. and Rahardjo, H. (1993). Soil Mechanics for Unsaturated Soils, John Wiley \& Sons, Inc.

Houston, S. L., Houston, W. N., and Wagner, A. M., 1994, "Laboratory Filter Paper Suction Measurements," Geotechnical testing Journal, Vol. 17, No. 2 pp. 185-194.

Likos W.J., Lu N. (2002). "Filter Paper Technique for Measuring Total Soil Suction,” Transportation Research Record: Journal of the Transportation Research Board, National Research Council, Washington D.C., No 1786, TRB, pp. 120-128.

Leong, E. C., He, L., and Rahardjo, H. (2002). "Factors Affecting the Filter Paper Method for Total and Matric Suction Measurements," Geotechnical Testing Journal, Vol. 25. No. 3, pp. 1-12.

Marinho, F.A.M., and Oliveira, O.M. (2005).” The Filter Paper Method Revisited," Geotechnical Testing Journal, Vol. 29, No. 3 pp. 1-9.

Ridley, A. M. (1995). "Discussion on 'Laboratory Filter Paper Suction Measurements" by Sandra L. Houston, William N. Houston, and Anne-Marie Wagner," Geotechnical Testing Journal, Vol. 18, No. 3, pp. 391-396. 